DOI: https://doi.org/10.32836/2521-666X/2018-1-59-21

УДК 336.71

\title{
Заруцька О.П.
}

доктор економічних наук, профресор,

Університет митної справи та фрінансів

\section{ВПРОВАДЖЕННЯ МЕТОДИКИ СТРУКТУРНО-ФУНКЦІОНАЛЬНИХ ГРУП У СИСТЕМУ УПРАВЛІННЯ СКЛАДНИМИ ЕКОНОМІЧНИМИ СИСТЕМАМИ}

У статті представлено результати групування однорідних елементів складних економічних систем для аналізу та моніторингу їх стану на макро-, мезо- та мікрорівнях. Формування структурно-функиіональних груп проводиться з використанням нейронної мережевої моделі кластеризаиії, а саме самоорганізаційних карт Кохонена. Запропоновані методи дають змогу забезпечити ранню діагностику загроз втрати фінансової стабільності банків, проводити класифікаџію їх бізнес-моделей. Відповідний інструментарій запропоновано поширити на моніторинг фондового ринку та виявлення операцій з підвищеним ризиком шахрайства й маніпулювань. Ефективний та об'єктивний моніторинг стану будь-якого сегменту фінансового ринку потребує виокремлення об 'єктів підвищеного ризику з використанням сучасних методів обробки даних звітності.

Ключові слова: бізнес-моделі банків, моніторинг фондового ринку, кластерний аналіз, нейронні мережі, структурно-функиіональні групи банків. 
В статье представлены результаты группировки однородных элементов сложных экономических систем для анализа и мониторинга их состояния на макро-, мезо- и микроуровнях. Формирование структурно-функииональных групп проводится с использованием нейронной сетевой модели кластеризации, а именно самоорганизующихся карт Кохонена. Предложенные методы позволяют обеспечить раннюю диагностику угроз потери финансовой стабильности банков, проводить классификаиию их бизнес-моделей. Соответствуюший инструментарий предложено расширить на мониторинг фондового рынка и выявление операций с повышенным риском моменничества и манипуляций. Эффективный и объективный мониторинг состояния любого сегмента финансового рынка требует выделения объектов повышенного риска с использованием современных методов обработки данных отчетности.

Ключевые слова: бизнес-модели банков, мониторинг фондового рынка, кластерный анализ, нейронные сети, структурно-функциональные группы банков.

\section{Zarutskaya O.P. IMPLEMENTATION OF STRUCTURAL-FUNCTIONAL GROUPS METHO- DOLOGY IN THE MANAGEMENT SYSTEM OF COMPLEX ECONOMIC SYSTEMS}

The article presents the results of grouping of homogeneous elements of complex economic systems for the analysis and monitoring of their state at the macro-meso-micro levels. The formation of structural and functional groups is carried out using a neural network clustering model - self-organization Kohonen maps (SOM). The proposed methods make it possible to provide early diagnosis of threats to the financial stability of banks, to classify their business models. Specific differences in the structure of assets, liabilities, income and expenses of the Bank determine the business model of development, the Bank's place in the market of banking services, the corresponding risk profile. Homogeneous groups of banks should be separate objects of banking supervision and require adequate approaches, depending on the characteristics of the financial condition and risk profile. The use of the method for the analysis of the banking system of Ukraine demonstrates the redistribution of resources in favor of the largest banks. In 2014, the mass liquidation of banks began and the size of groups of banks with an increased share of current funds of individuals significantly increased. The growth of the group is characterized by the movement of clients ' funds from liquidated to large state and banks by foreign shareholders, as well as the preferential placement on current accounts. Large state-owned banks and some daughters of foreign shareholders, which attracted the current resources of individuals, place assets in government securities. Credit operations of banks are reduced. From 2015, there are signs of excess liquidity, refocus resources on demand deposits, transactions, from credit short-term, focused on fee income. For banks in the cash operations, operational risk and increase the probability of violations of legislation on financial monitoring. It is proposed to distribute the appropriate tools for monitoring the stock market and identifying transactions with increased risk of fraud and manipulation. Effective and objective monitoring of the state of any segment of the financial market requires the identification of high risk objects using modern reporting methods. Stability of market development is largely determined by the availability of clear rules, brought to market participants, transparent and understandable methodological recommendations for risk assessment. The development of appropriate tools requires modern mathematical methods.

Key words: financial market stability, business-models of banks, stock market monitoring, cluster analysis, neural networks, structural and functional groups of banks.

Постановка проблеми. Дослідження складних економічних та фінансових систем, які поєднують велику кількість учасників, швидко й суттєво змінюються у часі, як правило, грунтується на аналізі звітності, яку надають ці об'єкти із тією чи іншою періодичністю. Якість аналізу багато в чому визначається повнотою, глибиною, точністю структурних індикаторів, які можна побудувати з використанням звітних даних. Розгорнута звітність, що охоплює різні аспекти діяльності об'єктів, дає змогу отримувати висновки про стан системи та іiі елементів, які мають наукову цінність та забезпечують ефективне практичне застосування. Але для оброблення великих масивів даних недостатньо використовувати лише традиційні статистичні інструменти, оскільки значення динамічних рядів великої розмірності, накопичених протягом тривалого часу, мають приховані внутрішні закономірності, виявлення яких потребує адекватних математичних підходів.

На наш погляд, для групування однорідних складних об'єктів доцільно використовувати методику нейронних мереж, а саме 
самоорганізаційних карт Кохонена, що надає важливу та зручну візуалізацію розміщення близьких об'єктів з урахуванням значень усіх показників (на кшталт географічної карти). Об'єкти зі стандартними, близькими характеристиками розміщуються поруч в центрі карти, а об'єкти, що мають значні відмінності, розташовуються на іiі границях. Саме на такі групи має звертати увагу регулятор ринку з метою запобігання втрати системної стабільності. Метод структурно-функціональних груп (метод СФГ) використано для дослідження профіля ризиків банків України та ризик-орієнтованого банківського нагляду [14]. Відповідний інструментарій пропонується поширити на дослідження типів бізнес-моделей банків та аналіз інших фінансових систем, а саме на моніторинг фондового ринку та виявлення операцій з підвищеним ризиком шахрайства й маніпулювань.

Забезпечення стабільного функціонування таких складних фінансових систем, як банківський ринок та фондовий ринок, потребує чіткого регламенту правил та умов діяльності, підходів до моніторингу, доведення до учасників ринку прозорих та зрозумілих методичних рекомендацій щодо оцінювання ризиків та правил застосування заходів впливу. Діяльність державного регулятора має спиратись на об'єктивні характеристики ринку, оцінювати поточний стан системи та виокремлювати об'єкти підвищеного ризику за допомогою значень відповідних структурних індикаторів, розрахованих за даними звітності учасників ринку.

Аналіз останніх досліджень і публікацій. Відповідно до Закону України «Про Національний банк України» [1] Національний банк (далі - НБУ) забезпечує збирання, складання та поширення даних фінансового та зовнішнього секторів економіки, зокрема грошово-кредитної та фінансової статистики (огляди фінансових корпорацій, депозити, кредити, процентні ставки депозитних корпорацій, цінні папери, фінансові рахунки сектору фінансових корпорацій), статистики індикаторів фінансової стійкості. Сучасна система пруденційного банківського нагляду спирається на різноманітну статистичну та фінансову звітність банків. Відповідно до «Правил організації статистичної звітності, що подається до Національного банку України», затверджених Постановою Правління НБУ від 1 березня 2016 року № 129 [7], близько 80 статистичних форм надається НБУ $з$ різною періодичністю. Перш за все фінансовий стан банку характеризує щоденний «Баланс банку» (Форма № 1Д), де відображена оперативна інформація щодо залишків за кожним з багатьох десятків балансових рахунків. Основні параметри кредитного ризику банки розкривають у таких звітних формах, як Форма № 302 (місячна) «Звіт про класифікацію кредитних операцій» та Форма № 604 (місячна) «Звіт про формування резерву для відшкодування можливих втрат за кредитними операціями». Ризик ліквідності можна проаналізувати за даними Форми № 631 (декадна, що складається на 1, 11, 21 число) «Звіт про структуру активів та зобов'язань за строками».

Більшість звітної інформації банків $€$ конфіденційною та вивчається лише у системі банківського нагляду. Водночас перелік відкритих даних про фінансовий стан банків забезпечує певні можливості для дослідження фінансового стану окремих банків та усієї банківської системи. Відповідно до вимог Закону України «Про бухгалтерський облік та фінансову звітність в Україні» [2] банки щоквартально оприлюднюють дані про власний капітал, активи, зобов'язання та фінансові результати на кінець періоду [11]. 32018 року на сайті НБУ оприлюднюються значення економічних нормативів у розрізі банків, інформація про розподіл кредитів, наданих фізичним та юридичним особам, за класами боржника. Відповідна інформація, що надається зі встановленою періодичністю, розкриває відомості про фінансовий стан банків та може бути використана для аналізу стану системи через поглиблене дослідження іiї складових.

Запропонований підхід має доповнити наявний інструментарій дослідження фінансової стабільності, що здійснює НБУ на підставі 
міжнародного досвіду, з метою ідентифікації ризиків фінансової стабільності в Україні [1; $6 ; 9 ; 10]$. При цьому зв'язок між показниками фінансового стану окремих банків та агрегованими даними фінансової стабільності проводиться за допомогою елементарного статистичного оброблення без формування та дослідження однорідних груп банків.

Протягом останніх років спостерігаються лише окремі невпевнені спроби групування банків не за масштабами та ознаками власності, а за деякими якісними характеристиками профіля ризиків та місця на ринку банківських послуг. Так, у 2015 році НБУ повідомив про застосування кластерного підходу до банківського нагляду, але цей підхід не отримав розвитку через нечітку та неоприлюднену систему формування кластерів. У 2018 році НБУ повідомив про впровадження концепцiï SREP ("Supervisory review and evaluation process") у банківському нагляді та групуванні банків за їх бізнес-моделями. При цьому процедура віднесення банку до однієі 3 п'яти бізнес-моделей, визначених НБУ, також не $\epsilon$ формалізованою та доведеною до банків. Оцінювання типів бізнес-моделей та належності окремих банків до конкретного типу нині здійснюється досить суб'єктивно, тобто без використання адекватного математичного інструментарію.

Враховуючи важливість дослідження розподілу ризиків у системі з великою кількістю банків, актуальною задачею вважаємо доповнення наявного підходу до аналізу фінансової стійкості методом СФГ. Інформація про стан окремих банків має бути систематизована та досліджена 3 точки зору кількісного оцінювання якісного стану банківської системи на основі детального аналізу фінансового стану окремих банків.

Використання інструментарію нейронних мереж, зокрема карт Кохонена, знайшло відображення в працях вітчизняних та іноземних вчених. Найчастіше самоорганізаційні карти покращують прогнозування банкрутства підприємств та банків, виявляючи зв'язок між фінансовими показниками $[12 ; 13 ; 18 ; 19$; 20]. Також карти Кохонена використовуються для прийняття рішення альтернативного вибору стратегій розвитку складних систем. Водночас широкі можливості та нерозкритий потенціал цього методу під час вирішення задачі виокремлення однорідних об'єктів для формалізації аналізу фінансової стійкості складної економічної системи та окремих об’єктів потребують подальшого розвитку.

Мета статті полягає в обгрунтуванні доцільності та переваг використання інструментарію нейронних мереж, а саме методики структурно-функціональних груп, побудованих з використанням карт Кохонена, для аналізу складних систем, оцінювання динамічних змін їх характеристик та виокремлення об’єктів, що мають підвищений ризик.

Виклад основного матеріалу. Постановка задачі групування однорідних банків у системі банківського нагляду та контролю фінансової стійкості системи 3 використанням аналізу структурно-функціональних груп стала наслідком спостереження відмінності реакції різних типів банків на кризи 2010 та 2014 років. Специфічні відмінності структури активів, пасивів, доходів та витрат банку, які оцінюються одночасно за усім спектром значень, визначають його бізнес-модель розвитку, місце на ринку банківських послуг, відповідний профіль ризику. Однорідні групи банків мають бути відокремленими об'єктами банківського нагляду та потребують адекватних підходів, диференційованих залежно від особливостей фінансового стану та профіля ризику. Інструментарій пруденційного нагляду, на наш погляд, не може бути універсальним для банків різних типів, а спрямування ресурсів нагляду у сфери підвищеного ризику сприятиме його ефективності. Більш детально про використання методу СФГ та властивості структурно-функціональних груп можна прочитати в роботі [15].

Проведені дослідження продемонстрували переваги методу для аналізу об'єктів, що мають такі характеристики.

1) Складна система має велику кількість елементів, кожний $з$ яких також має складну природу та вимірюється значеннями відповідних структурних індикаторів. Так, банківська 
система протягом 15 років дослідження охоплювала від 200 до 80 банків, для кожного 3 яких під час формування методики СФГ розраховувалося близько 40 показників, що визначали особливості фінансового стану, профіля ризиків та місця на ринку банківських послуг.

2) Система динамічна та змінюється у часі, а методи аналізу іiї стану та виявлення найбільш уразливих об'єктів не можуть бути постійно однаковими. Наприклад, протягом кількох банківських криз до груп підвищених ризиків потрапляли банки з високими процентними ставками (криза ліквідності), зі збитковими операціями з іноземною валютою (падіння курсу гривні), 3 неякісними активами (загальна фінансова криза). В умовах великої вразливості системи обов'язковим елементом регулювання $\epsilon$ аналіз профіля ризиків та спрямування ресурсів банківського нагляду у сфери підвищеної вірогідності шоків. Крім того, в будь-який період розвитку для кожної групи банків необхідно визначати адекватний інструментарій контролю, перелік маркерних показників та методів реагування. Процедури нагляду мають різнитися для банків залежно від їх профіля ризику та місця на ринку банківських послуг.

3) Існує достатній обсяг звітності від об'єктів системи, що дає змогу побудувати структурні індикатори та охопити найбільш важливі аспекти діяльності системи.

За наявності трьох складових вважаємо доцільним використовувати саме метод СФГ, який забезпечує групування однорідних об'єктів з використанням великих масивів звітних даних, візуалізацію результатів групування на карті Кохонена та інтерпретацію результатів. Використання методу дає великі переваги оцінювання стану системи на макро-, мезо та мікрорівнях.

Насамперед метод СФГ дає змогу кількісно оцінити поточний стан усієї системи порівняно з їі попереднім станом. Про характеристики системи свідчать розміри та характеристики груп банків, їх положення на карті Кохонена, середні значення маркерних структурних індикаторів. При цьому якісні зміни макрорівня визначаються в конкретних кіль- кісних показниках, а саме розмірах та характеристиках структурно-функціональних груп 3 підвищеним ризиком.

Також метод СФГ дає змогу оцінити поточний стан кожної структурно-функціональної групи у кількісній формі. На рівні однорідних груп банків можна досліджувати ключові зміни профіля ризиків системи. Так, у період кризи 2010 року спостерігалося зростання обсягу групи банків 3 неякісними активами та збитковим фінансовим результатом, за масової ліквідації банків у 2015 році зросла група з поточними ресурсами фізичних осіб, у 2018 році увагу привертає зростання кількості банків, що розміщують кошти на ринку ОВДП.

Нарешті, метод СФГ дає змогу побудувати траєкторію кожного окремого банку на карті Кохонена, дослідити його фінансовий стан, порівняти зі стратегічними планами та визначити профіль ризику. Метод дає змогу моделювати положення банку на карті за зміни його характеристик, що надає корисний інструментарій запобігання втраті фінансової стійкості. Також можна отримати корисну інформацію про наближення до точок розташування банків-банкрутів на карті Кохонена. Якщо траєкторія діючого банку наближається до таких критичних точок, визначених протягом періоду дослідження, банку необхідно врахувати негативний досвід попередників для запобігання банкрутству.

Структурно-функціональний аналіз визначається у філософії як метод дослідження системних об'єктів, насамперед соціально-економічних систем та різних форм суспільного життя, на основі виділення в них структурних складових та їх ролей (функцій) у системі. У кібернетиці структурно-функціональний підхід до опису та пояснення системи досліджує іiі елементи й залежності між ними в рамках єдиного цілого. Кожен елемент виконує визначені функції, що задовольняють потреби системи. Діяльність елементів системи програмується загальною структурною організацією, займаними ними позиціями та виконуваними ролями. Сутність структурно-функціонального методу полягає в розді- 
ленні складного об'єкта на складові частини, вивченні зв'язку між ними та визначенні притаманних їм специфічних функцій, спрямованих на задоволення відповідних потреб системи, управління з урахуванням цілісності останньої та іiі взаємодії із зовнішнім середовищем. Головна задача управління великими системами полягає в пошуку та реалізації управлінських впливів, які в умовах зовнішніх та внутрішніх збурень зможуть забезпечити гомеостатичний стан функціонування й розвитку системи.

Системні дослідження показують, що визначальною умовою поведінки складних економічних систем $\epsilon$ їх нерівномірна самоорганізація, функціональна стійкість в неврівноважених умовах. Якщо стан рівноваги $е$ необхідною умовою стаціонарного існування управлінських систем, то неврівноважений стан $\epsilon$ істотним моментом переходу в новий стан, в якому управлінська система набуває іншого рівня організації та продуктивності. Набуваючи в нових умовах функціонування стабілізуючого стану, управлінська система проходить свої врівноважені стани як проміжні етапи на траєкторіях неврівноваженої самоорганізації.

Низка різноманітних фінансових криз останніх десятирічь свідчить про актуальність застосування структурно-функціонального підходу до виявлення суттєвих змін у різних сегментах ринку. Впровадження методу СФГ у банківському нагляді особливо актуально сьогодні, коли НБУ розробляє концепцію SREP ("Supervisory review and evaluation process") та здійснює групування банків за бізнес-моделями, визначаючи їх досить суб' єктивно. Між тим категорія бізнес-моделі є спорідненою зі структурно-функціональною групою банку, що характеризує особливості продуктів, тарифів, місця на ринку, що проявляються у складових доходів, витрат, активів та пасивів. За використання методу СФГ класифікація бізнес-моделей випливає з об'єктивних характеристик системи в конкретному бізнес-середовищі саме у визначеному періоді розвитку. Групи формуються без суб'єктивного впливу, тобто лише за суттєвими відхиленнями зна- чень структурних показників, що відображають реальний стан системи.

Використання методу СФГ для оцінювання фінансової стійкості банківської системи та банківського нагляду

Застосування міжнародних стандартів банківського нагляду в Україні вимагає врахування специфіки вітчизняної банківської системи, зокрема існування значної кількості банків, які суттєво відрізняються за обсягами та структурою активів, характеристиками ризиків та політикою управління ними, стратегією позиціонування на ринку, чутливістю до екзогенних та ендогенних шоків. Навіть суттєве скорочення кількості банків упродовж 2015-2016 років відбулося зі збереженням специфіки профіля ризиків кожної групи.

На цьому етапі методологія банківського нагляду потребує, на наш погляд, переходу від універсальної методики оцінювання фінансової стійкості усіх банків до застосування диференційованих підходів до конкретних груп банків залежно від їх профіля ризиків, переліку основних операцій, джерел отримання прибутку, структури основних статей балансу, особливостей клієнтської бази тощо.

В процесі дослідження структури банківської системи України нами сформульовано ідею доцільності та можливості виокремлення однорідних груп банків, які є близькими:

1) за структурою основних агрегатів активів, пасивів, доходів та витрат;

2) за пріоритетами в наданні послуг;

3) за рівнем та структурою основних видів банківських ризиків;

4) за реакцією на зовнішні шоки.

Такі однорідні структурно-функціональні групи банків, що протягом тривалого періоду поєднують банки 3 відповідними характеристиками, мають бути відокремленими та специфічними об'єктами наглядової діяльності. Це створює наукове підгрунтя для диференціації наглядових заходів для ризиків, які виникають на трьох різних рівнях, а саме в окремому банку, структурно-функціональній групі та банківській системі загалом.

Під час вибору адекватних заходів впливу щодо банків має використовуватися послі- 
довний та обгрунтований методологічний апарат, що дає змогу оцінювати ефективність таких заходів та моделювати їх наслідки. Наглядові режими мають бути прозорими та ефективними як з точки зору регулятора, так і $з$ точки зору керівництва банку, зацікавленого в підвищенні його фінансової стійкості. Саме для адекватного оцінювання фінансового стану банків та забезпечення своєчасних наглядових дій пропонується використовувати метод СФГ.

Для реалізації визначеного підходу використовується метод побудови карти Кохонена, яка одночасно враховує різні аспекти фінансової стійкості банків, дає змогу виявляти близькі об'єкти за багатомірними базами даних їх звітності та представляти їх у зручній для інтерпретації формі. На основі аналізу карт Кохонена, побудованих послідовно на квартальні дати фінансових звітів банків з 2003 року, ми запропонували метод СФГ формування узагальненої схематичної карти розподілу банків на однорідні групи, оцінювання фінансової стійкості банківської системи, що демонструє взаємне розташування груп, характеристики ї розмірів та середніх значень фінансових показників.

Метод СФГ дає змогу поєднати різні аспекти та напрями аналізу фінансової стійкості банків, що розкриваються через систему показників, серед яких слід назвати обсяг та структуру власних коштів, рівень дохідності та прибутковості, дотримання встановлених показників ліквідності, платоспроможності, концентрацію активів та пасивів, обсяг створених резервів під кредитні ризики, ліміти валютної позиції.

Дослідження фінансової стійкості банків 3 використанням методу СФГ демонструє стійкі структурно-функціональні відхилення від рівноважного розподілу основних агрегатів активів та пасивів, доходів та витрат для більшості українських банків. За допомогою стандартизованої процедури побудови однорідних груп банків, що приймають вигляд відокремлених областей карти Кохонена, виявляються стійкі зв'язки банків у межах груп 3 притаманними їм характеристиками.
Інструментарій нейронних мереж забезпечує одночасне врахування структурних характеристик банків та візуальне представлення великих масивів даних, що складаються зі значної кількості параметрів.

Фінансово стійкими є банки зі збалансованою структурою балансу, тобто контрольованим рівнем основних видів ризиків. Інші групи характеризуються специфічними характеристиками. Географічне сусідство областей на карті Кохонена $є$ свідченням близьких характеристик, діагональна відстань - значних відмінностей. Навіть якщо функціональна спеціалізація, що супроводжується відповідним структурним дисбалансом, забезпечує банку певні тимчасові переваги, iї наслідком обов'язково є підвищення вразливості банку до впливу негативних зовнішніх чинників, нездатність до динамічної адаптації до трансформаційних змін на ринку. Цей висновок підтверджений значною кількістю банків, що втратили фінансову стійкість під час фінансово-економічної кризи 2008-2009 років.

3 огляду на загальний стійкий розподіл ринку банківських послуг під час оцінювання ризику необхідно спиратися саме на ознаки того сегменту ринку, до якого належить конкретний банк. Природа структурно-функціональних характеристик банку має бути контрольованою, щоб не перетворюватися на додатковий структурний ризик, притаманний більшості банків. Наприклад, група банків роздрібного кредитування має підвищений рівень комісійних доходів у структурі прибутку, великий розмір резервів під кредитні ризики порівняно із середнім значенням у системі. Група банків, залежних від міжбанківських ресурсів, характеризується підвищеними валютними ризиками через значну частку зобов'язань в іноземній валюті. Виходячи 3 вищезазначеного, фінансово стійкими вважаємо лише банки зі збалансованою структурою активів та пасивів.

Для побудови карт Кохонена використано програмний продукт Viscovery SOMine. Багатомірний масив даних представляється у двомірному просторі як географічна карта. 
У кластерах поєднуються близькі за значенням структурних індикаторів «образи» банків на різні звітні дати. Як зазначалося раніше, географічна відстань між будьякими точками самоорганізаційних карт $\epsilon$ ступенем подібності їх фінансових показників, тобто характеристик бізнес-моделей та профіля ризиків.

Вхідні дані мають вигляд табл. 1.

Таблиця 1

\section{Структура вхідних даних для побудови СФГ банків}

\begin{tabular}{|c|c|c|c|c|}
\hline $\begin{array}{c}\text { Звітна } \\
\text { дата }\end{array}$ & Банки & \multicolumn{3}{|c|}{ Структурні індикатори (CI) } \\
\hline \multirow{4}{*}{ Дата 1 } & Банк 1 & & & \\
\cline { 2 - 5 } & Банк 2 & & & \\
\cline { 2 - 5 } & $\ldots$ & & & \\
\hline \multirow{3}{*}{ Дата 2 } & Банк 1 & & & \\
\cline { 2 - 5 } & Банк 2 & & & \\
\cline { 2 - 5 } & $\ldots$ & & & \\
\hline
\end{tabular}

Дослідження проводиться щоквартально на основі оприлюдненої фінансової звітності та складається 35 етапів.

1) Розрахунок CI за звітністю усіх діючих банків на чергову звітну дату, доповнення бази даних та побудова карти Кохонена.

2) Аналіз отриманих кластерів, порівняння структури карти 3 попередньою, оцінка середніх значень СI для кожного кластера, поєднання окремих близьких кластерів у структурно-функціональні групи.

3) Дослідження змін характеристик структурно-функціональних груп, їх положення на карті та розміру, інтерпретація змін на макрорівні.

4) Дослідження змін характеристик кожного банку, його траєкторії на карті, близького положення до місця розташування банків, ліквідованих у попередні періоди, можливе моделювання рівня фінансової стійкості та траєкторії його переміщення під час змін СI (стрес-тестування), інтерпретація змін на макрорівні.

5) Узагальнююча оцінка стану банківської системи, причини виведення ринку банків, перерозподілу на ринку банківських послуг.
Слід зазначити, що висновки про фінансовий стан банків, отримані за традиційними методиками аналізу фінансового стану, узгоджуються з результатами виокремлення структурно-функціональних груп. Наприклад, будь-який банк завжди змінює траєкторію на карті під час вжиття важких заходів впливу банківського нагляду або за суттєвих змін у системі менеджменту самого банку. Також встановлено, що банки 3 пов'язаними акціонерами, як правило, перебувають в одній групі на невеликій відстані на карті. Перелік структурних індикаторів може бути розширений та уточнений під час виходу за межі оприлюдненої звітності банків та використання даних статистичної звітності банків, що застосовуються банківським наглядом.

Використання методу СФГ для аналізу вітчизняної банківської системи останніх років дало змогу дійти висновку про перерозподіл ресурсів на користь найбільших банків. 32014 року разом 3 масовою ліквідацією банків суттєво збільшилися розміри СФГ банків, ресурсна база яких має підвищену частку поточних коштів фізичних осіб. Зростання групи характеризує рух коштів клієнтів від ліквідованих до великих державних банків та банків з іноземними акціонерами, а також переважне розміщення на поточних рахунках. Водночас для розвитку кредитних операцій банкам потрібні довгі строкові ресурси.

Причиною ліквідації багатьох банків стали підвищені валютні ризики та збитки під час переоцінювання активів за стрибків валютного курсу. Також СФГ проблемних банків формувалися за підвищених операційних ризиках у зв'язку зі значними операціями 3 готівкою, недотриманням законодавства 3 фінансового моніторингу. Проблемні банки зі збитками та підвищеними кредитними ризиками стали останнім часом меншими за розмірами, у структурі пасивів цих банків зросла частка строкових коштів фізичних осіб, скоротилися міжбанківські кредити, в активах зменшилась частка іноземної валюти. Споживчі кредити стабільно продовжують мати високу частку в проблемних банках. 
Великі державні банки та деякі «дочки» іноземних акціонерів, що залучили поточні ресурси фізичних осіб, розміщують активи в державних цінних паперах. Кредитні операції банків скорочуються. Значна кількість позичальників має підвищене кредитне навантаження або недостатню платоспроможність, а також обмежені надто високими кредитними ставками. Більшість банків має накопичені проблемні кредити та обслуговує непрацюючі активи.

Із середини 2015 року спостерігаються ознаки надлишкової ліквідності банків, переорієнтації ресурсів на кошти до запитання, операцій - від кредитних до короткострокових, спрямованих на комісійні доходи. Кількість банків, які мають підвищені високоліквідні активи, зростає. Для банків, що спеціалізуються на операціях з готівкою, підвищуються операційні ризики та ймовірність порушення законодавства з фінансового моніторингу.

Виявлення головних тенденцій розвитку банківської системи надає банківському нагляду важливі переваги для оцінювання профіля ризиків та ефективного спрямування ресурсів. Як зазначалося раніше, згідно 3 нормативними документами, функцію дослідження фінансової стабільності НБУ здійснює з метою ідентифікації відповідних ризиків в Україні. Для виконання цієї функції необхідний системний огляд сучасного стану банківського сектору. Так, у «Звіті про фінансову стабільність» станом червень 2018 року НБУ жодним чином не відобразив зростаючі ризики концентрації активів в ОВДП під час побудови карти ризиків. Згідно з оцінкою НБУ кредитний ризик знизився завдяки поліпшенню фінансового стану населення й бізнесу, реструктуризації проблемної заборгованості великих позичальників, зниженню частки незарезервованих дефолтних кредитів. До кінця року очікується подальше зміцнення фінансового стану позичальників, що сприятиме відновленню якості кредитів [10]. Погоджуючись 3 висновком про низький ризик ліквідності через надлишковість високоліквідних активів, маємо звернути увагу на переважне формування ресурсної бази банків поточними коштами фізичних осіб. Відповідна характеристика ризику не врахована у звіті НБУ. Не є безумовним висновок про невисокий валютний ризик, що сформульовано у звіті таким чином: рівень доларизації активів та пасивів банків залишається високим, проте відкрита валютна позиція більшості фінансових установ $є$ незначною. Навіть якщо валютний ризик реалізується для меншості установ та призведе до їх ліквідації, чергова хвиля втрати довіри до системи позначиться на кожному банку.

Слід підкреслити, що формування груп банків зі специфічними характеристиками 3 використанням методу СФГ дає змогу виокремити сфери підвищених ризиків, прогнозувати їх розвиток за допомогою стрес-тестування та запобігати втраті фінансової стійкості банківської системи.

Використання методу СФГ у системі моніторингу фондового ринку та виявлення операцій $з$ підвищеним ризиком шахрайства й маніпулювань

На відміну від розвинутої нормативно-правової бази для регулювання діяльності банків, моніторинг фондового ринку України ще не розбудований щодо систематичного контролю ризиків, виявлення фактів шахрайства та маніпулювання на ринку. Слід зазначити, що задачі Національної комісії $з$ цінних паперів та фондового ринку (НКЦПФР) щодо організації роботи ринку більш вузькі, ніж функції НБУ стосовно банківського нагляду й управління фінансовою стійкістю банківської системи. Водночас у діяльності цих державних регуляторів $\epsilon$ важлива спільна риса: моніторинг складної фінансової системи потребує чіткої та прозорої методики оцінювання iii поточного стану, конкретних структурних індикаторів або показників діяльності учасників ринку та алгоритму опрацювання великих масивів значень цих показників. У НКЦПФР нині відсутні ці складові для виконання функцій, покладених чинним законодавством щодо створення інституціональної основи для запобігання зловживання ринком.

Сьогодні фахівці наголошують на необхідності змін в організації роботи фондового 
ринку, спрямованих на розвиток прозорої законодавчо врегульованої аналітичної складової у питаннях виявлення фактів маніпулювання. При цьому, згідно 3 їх оцінкою, практичне здійснення полягає в забезпеченні роботи системи сертифікованим софтом для роботи 3 масивами інформації про транзакції [16].

Справді, сучасний організований фондовий ринок має всі ознаки складної системи, елементи якої характеризуються кількісними показниками звітності, що потребуе комплексного дослідження з подальшим узагальненням наявних ризиків зловживання, виявленням сфер підвищених ризиків та спрямуванням на них уваги представників НКЦПФР. На організованому фондовому ринку України у 2017 році укладено 124 тисячі біржових контрактів. 3 огляду на обсяги торгів без спеціальної системи обробки звітності учасників біржових торгів об'єктивний та ефективний моніторинг стану ринку не $\epsilon$ можливим.

Слід зазначити, що нормативно-правова база НКЦПФР, як правило, характеризується відсутністю достатніх та точних формулювань, часто спирається на нечіткі та неформалізовані поняття, такі як «значне коливання цін», «суттєве відхилення», «очевидний економічний сенс». Головною проблемою, на наш погляд, $є$ відсутність системного підходу до аналізу стану ринку та виявлення ризику зловживань. Регулятору необхідне чітке розуміння основних процесів, їх причин та наслідків, класифікації ризиків та стратегії необхідних заходів для запобігання правопорушень на ринку цінних паперів.

Одним з базових документів щодо виявлення маніпулювання на ринку цінних паперів та правильності кваліфікації виявлених правопорушень $\epsilon$ «Методичні рекомендації зі встановлення наявності ознак маніпулювання цінами на фондовому ринку», затверджені Наказом Голови НКЦПФР від 19 серпня 2013 року № 445 [8] (далі - Методичні рекомендації). Більшість понять та ознак, які використовує цей документ, не $є$ кількісними, однозначними та чіткими. Через відсутність конкретних формулювань умов настання подій, пов'язаних 3 певними ознаками, виконання відповідних норм не є очевидним, прозорим та зрозумілим для учасників ринку.

Розглянемо деякі норми розділу 3 Методичних рекомендацій, який присвячений встановленню наявності окремих ознак маніпулювання цінами на фондовому ринку. Для кожної ознаки, визначеної статтею 10 Закону України «Про державне регулювання ринку цінних паперів в Україні» [3], перелічені умови наявності, що фактично лише повторюють формулювання ознаки в законі, не конкретизуючи іii.

Наприклад, перша ознака маніпулювання цінами на ринку цінних паперів сформульована так: здійснення або намагання здійснити операції чи надання заявки на купівлю або продаж фінансових інструментів, які надають або можуть надавати уявлення щодо поставки, придбання або ціни фінансового інструмента, що не відповідають дійсності, а також вчиняються одноосібно або за попередньою змовою групою осіб та приводять до встановлення інших цін, ніж ті, що існували б за відсутності таких операцій або заявок. Хоча формулювання цієї ознаки націлене на виявлення фактів неправомірного впливу на ціну фінансових інструментів, порядок обрахування ринкової ціни та аналізу такого впливу в документі не передбачений.

Методичні рекомендації жодним чином не конкретизують норму закону щодо виявлення умов встановлення інших цін, ніж ті, що існували б за відсутності таких операцій або заявок. Якщо враховувати факт, що будьякі ринкові ціни складаються на підставі балансу між попитом та пропозицією, то можна сказати, що кожна заявка має вплив на ціну та може підпадати під відповідну ознаку. Залишається загадковим використання таких понять, як «ціна цінного паперу, яка не відповідає дійсності» або «інші ціни, ніж ті, що існували б за відсутності таких операцій або заявок».

Для виявлення фактів маніпулювання цінами регулятор ринку має володіти інформацією про середній рівень цін та основні чинники, які впливають на ринок. Серед 
великої кількості звичайних подій виявляти та контролювати надзвичайні можна лише 3 використанням чітких граничних параметрів ринку та адекватного інструментарію.

Хоча Методичні рекомендації окреслюють окремі напрями опрацювання статистичної інформації, в документі відсутні критерії та підходи, необхідні для побудови системи моніторингу ринку. Так, для виявлення першої ознаки маніпулювання цінами пропонується, зокрема, звертати увагу на такі фактори:

- динаміка ціни фінансового інструмента за період до та після дати можливого маніпулювання цінами;

- обсяги торгів цінними паперами на фондовій біржі, на якій здійснювалося маніпулювання, та на інших фондових біржах;

- факт повернення ціни цінного папера на попередній рівень після маніпулювання цін $з$ цим цінним папером.

Втім, без єдиного зрозумілого та прозорого визначення таких чинників їх інтерпретація залишається суто суб'єктивною та не може забезпечити виконання функцій контролю прозорості операцій на ринку, що має виконувати НКЦПФН.

Методичними рекомендаціями також сформульована науково-практична задача оцінювання дійсної вартості фінансового інструмента, але не запропоновано жодного алгоритму такого аналізу. Перелік чинників, які, на думку розробників цього документа, визначають вартість фінансового інструмента, не знімає проблеми неоднозначного трактування отриманих результатів. Для оцінювання вартості будь-якого фінансового інструмента пропонується лише проаналізувати такі складові:

- фінансові документи емітента цінних паперів (без уточнення);

- аудиторський висновок емітента;

- капіталізація емітента;

- новини в засобах масової інформації щодо злиття, приєднання, поділу, виділу, перетворення емітента цінних паперів.

Зрозуміло, що висновки про вартість цінного папера, отримані за цією рекомендацією різними виконавцями, мають суттєво різнитися між собою.

Як свідчить практика правозастосування, не тільки зміна ціни, але й практична відсутність зміни ціни може кваліфікуватися як ознака маніпулювання. В результаті цього до учасників торгів на різних фондових біржах застосовано принципово різні підходи до кваліфікації ознак маніпулювання цінами, незважаючи на аналогічність чи повну ідентичність інструмента, емітента, ціни, періоду торгів, ознаки маніпулювання.

На наш погляд, забезпечення моніторингу ознак маніпулювання цінами є можливим лише на основі узагальнення звітності про операції на ринку цінних паперів та встановлення кількісних підходів до оцінювання умов настання тієї чи іншої ознаки. Для кожного виду цінних паперів, що обертаються на ринку, необхідно створити базу даних 3 інформацію про емітентів та їх структуру власності, обсяги й ціни продажу, умови заявок протягом торговельного дня, умови договорів купівлі-продажу за підсумками торгів. 3 огляду на досить розгалужену структуру ринку та значну кількість операцій відповідна інформація має опрацьовуватись автоматично в режимі реального часу. Для оброблення отриманих масивів інформації доцільно використовувати метод СФГ, який зорієнтований на пошук закономірностей у великих масивах даних.

Вхідні дані про обсяги, ціни та умови торгів поєднуються у вигляді табл. 2 .

У схематичному вигляді алгоритм моніторингу цін може бути представлений так.

Таблиця 2

Структура вхідних даних для побудови СФГ операцій

\begin{tabular}{|c|c|c|c|c|}
\hline $\begin{array}{c}\text { 3вітна } \\
\text { дата }\end{array}$ & Операції & \multicolumn{2}{|c|}{$\begin{array}{c}\text { Структурні } \\
\text { індикатори (CI) }\end{array}$} \\
\hline \multirow{2}{*}{ Дата 1 } & Операція 1 & & & \\
\cline { 2 - 5 } & Операція 2 & & & \\
\cline { 2 - 5 } & $\ldots$ & & & \\
\hline \multirow{3}{*}{ Дата 2 } & Операція 1 & & & \\
\cline { 2 - 5 } & Операція 2 & & & \\
\cline { 2 - 5 } & $\ldots$ & & & \\
\hline
\end{tabular}


Після формування числових рядів зі значеннями ціни та обсягу продажу для кожного фінансового інструмента на їх основі будується карта Кохонена, що поєднує однорідні події, тобто торги, за умовами, які незначно відрізняються від середніх. При цьому в окремі групи автоматично виділяються операції, умови яких суттєво відрізняються від інших. Саме такі групи з відмінностями від середніх умов необхідно досліджувати задля пошуку фактів маніпулювання цінами. Формування груп проводиться за значенням числових рядів з ринковими цінами та обсягами торгів без втручання користувача.

Питання розроблення та впровадження єдиних і прозорих правил моніторингу фондового ринку набуває особливої актуальності саме зараз, коли опрацьовуються та обговорюються законопроекти щодо наближення правил роботи вітчизняних ринків до вимог євродиректив та регламентів СС [4; 5]. Згідно 3 оцінками фахівців у законопроектах відсутні регламентні положення щодо правил роботи ринків, санкцій для їх учасників тощо. Замість необхідних формалізованих та прозорих правил роботи прописано виключні повноваження регулятора. Прийняття відповідних законів без розроблення методологічної бази руйнує фондовий ринок та несе величезні корупційні ризики [17]. 3 огляду на важливу роль фондового ринку в розбудові економіки України проблему розроблення прозорого та ефективного методичного апарату моніторингу ризиків, необхідну для забезпечення його розвитку, важко переоцінити.

Висновки. На основі вищевикладеного можна зробити такі висновки.

1) Сучасні фінансові ринки мають складну структуру, характеризуються різноманітними ризиками, які їх учасники можуть транслювати та поширювати на всю економіку. Без задовільного регулювання банківські, фондові та товарні ринки стають джерелом фінансових шоків, тоді як в умовах прозорого та контрольованого моніторингу ризиків учасники ринку здатні підтримувати та поширювати стабільність до всіх пов'язаних контрагентів. Для належного виконання функцій державного регулятора необхідні чіткі правила діяльності, прозорий порядок застосування санкцій за порушення умов. Методика моніторингу та санкцій має бути зрозумілою та доведеною до учасників ринку.

2) Управління фінансовою стійкістю банківської системи, банківське регулювання й нагляд в Україні потребують переходу до диференційованого інструментарію, залежного від профіля ризиків банків. Враховуючи велику кількість банків, рекомендуємо поєднувати їх в однорідні структурно-функціональні групи, які $\epsilon$ близькими за структурою основних агрегатів активів, пасивів, доходів та витрат; за пріоритетами в наданні послуг; за рівнем та структурою основних видів банківських ризиків; за реакцією на зовнішні шоки.

3) Організація роботи вітчизняного фондового ринку потребує докорінних змін, спрямованих на розвиток прозорої законодавчо врегульованої аналітичної складової щодо виявлення фактів маніпулювання цінами. Забезпечення моніторингу ознак маніпулювання цінами $є$ можливим лише на основі узагальнення звітності про операції на ринку цінних паперів та встановлення кількісних підходів до оцінювання умов прояву тієї чи іншої ознаки. 3 огляду на досить розгалужену структуру ринку та значну кількість операцій відповідна інформація має опрацьовуватися автоматично в режимі реального часу.

4) Методика оцінювання стану складних фінансових систем та виокремлення об'єктів підвищеного ризику має грунтуватись на значеннях відповідних структурних індикаторів, які характеризуються особливостями профіля ризику підсистем ринку. Для оброблення великих масивів даних не є достатніми традиційні статистичні інструменти, оскільки значення динамічних рядів великої розмірності, накопичених протягом тривалого часу, мають приховані внутрішні закономірності, виявлення яких потребує адекватних математичних підходів. Для опрацювання великих масивів інформації рекомендується використовувати метод СФГ, який продемонстрував важливі переваги в процесах прогнозування та управління банківськими ризиками. 


\section{Список використаних джерел:}

1. Про Національний банк України: Закон України від 20 травня 1999 року № 679-XIV. URL: http://zakon1.rada.gov.ua/laws/show/679-14.

2. Про бухгалтерський облік та фінансову звітність в Україні: Закон України від 16 липня 1999 року № 996-XIV. URL: http://search.ligazakon.ua/1_doc2.nsf/link1//T990996.html.

3. Про державне регулювання ринку цінних паперів в Україні: Закон України від 30 жовтня 1996 року № 448/96-BP. URL: http://search.ligazakon.ua/ /1_doc2.nsf/link1/Z960448.html.

4. Про ринки капіталу та організовані товарні ринки: Проект Закону України від 1 вересня 2017 року № 7055. URL: http://search.ligazakon.ua/1_doc2.nsf/link1//JH5FZ00I.html.

5. Про внесення змін до деяких законодавчих актів України щодо захисту інвесторів від зловживань на ринках капіталу: Проект Закону України від 4 липня 2018 року № 6303-д. URL: http://search.ligazakon.ua/1_doc2.nsf/link1//JH4V37LI.html.

6. Методичні рекомендації щодо організації та функціонування систем ризик-менеджменту в банках України: Постанова Правління Національного банку України від 2 серпня 2004 року № 361. URL: https://bank.gov.ua/doccatalog//document?id=36985.

7. Правила організації статистичної звітності, що подається до Національного банку України: Постанова Правління НБУ від 1 березня 2016 року № 129. URL: http://search.ligazakon.ua/ 1_doc2.nsf/link1/PB16025Z.html.

8. Методичні рекомендації зі встановлення наявності ознак маніпулювання цінами на фондовому ринку: Наказ Голови НКЦПФР від 19 серпня 2013 року № 445. URL: http://search.ligazakon.ua/1_doc2.nsf/link1/RE19783.html.

9. Основні принципи еффективного банківського нагляду // Національний банк України: офіційний сайт. URL: https://bank.gov.ua/control/uk/publish//article?art_id=75529\&cat_id=17823467.

10. Звіт про фінансову стабільність: червень 2018 року // Національний банк України: офіційний сайт. URL: https://bank.gov.ua/doccatalog/document?id=71475860.

11. Фінансова звітність банків України // Національний банк України: офіційний сайт. URL: http://www.bank.gov.ua/control/uk/publish/category?cat_id=64097.

12. Аникин В.И. Визуальное табличное моделирование клеточных автоматов в Microsoft Excel: монография. Тольятти: ПВГУС, 2013324 с.

13. Дебок Г. Анализ финансовых данных с помощью самоорганизующихся карт. Москва: АЛЬПИНА, 2001. 317 с.

14. Заруцька О.П. Банківський нагляд з використанням структурно-функціонального аналізу: теорія, світовий і вітчизняний досвід: монографія. Суми: ДВНЗ «УАБС НБУ», 2013. 379 с.

15. Заруцька О.П., Згонік С.В., Косюга В.В. Структурно-функціональні характеристики банківської системи України та шляхи підвищення ії ефективності. Науковий погляд: економіка та управління. 2017. № 2 (58). С. 77-96.

16. Кошовий О.В. Фондовий ринок: що відбувається з експертним забезпеченням? Юридична газета. 2018. № 24-25. С. 42-43.

17. Кошевой А.В. Что не так с законопроектами НКЦБФР? ZN.UA. 2018. URL: https://zn.ua/ ECONOMICS/chto-ne-tak-s-zakonoproektami-nkcbfr-288727_html.

18. Любіч О.О., Бортніков Г.П., Панасенко Г.О. Аналіз бізнес-моделі державних банків в Україні. Фінанси України. 2016. № 10. С. 7-38.

19. Павлов Р.А. Рання діагностика банкрутства банків: дис. ... канд. екон. наук: спец. 08.00.08; ДНУ. Дніпропетровськ, 2008. URL: https://essuir.sumdu.edu.ua//bitstream/123456789/51370/7/ Pavlov_\%20Rannia_diahnostyka\%20.pdf.

20. Severin. E. Self-organizing maps in corporate finance: Quantitative and qualitative analysis of debt and leasing self-organizing maps in corporate finance: Quantitative and qualitative analysis of debt and leasing. NEUROCOMPUTING. 2010. Vol. 73. № 10-12. P. 2061-2067. 